Randi Novrizal, Jumiatil Pelayanan Pembuatan Akta Kelahiran di Dinas Kependudukan dan Pencatatan Sipil Kabupaten Kuantan Singingi

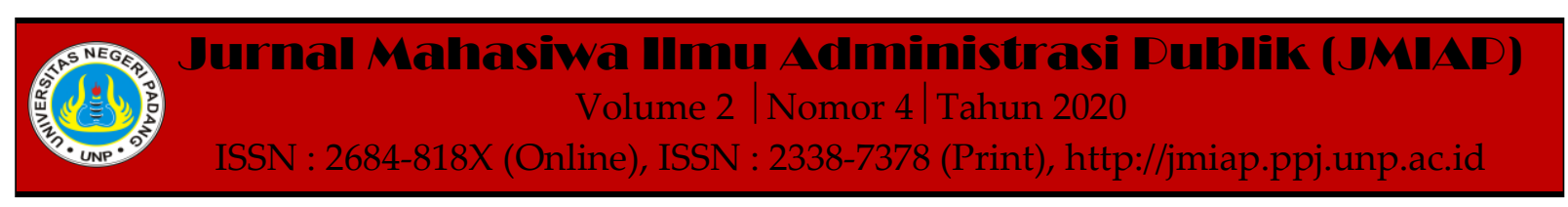

\title{
PELAYANAN PEMBUATAN AKTA KELAHIRAN DI DINAS KEPENDUDUKAN DAN PENCATATAN SIPIL KABUPATEN KUANTAN SINGINGI
}

\author{
Randi Novrizal $^{1(a)}$, Jumiati $^{2(b)}$ \\ ${ }^{1}$ Jurusan Ilmu Administrasi Negara, Universitas Negeri Padang \\ ${ }^{2}$ Jurusan Ilmu Administrasi Negara, Universitas Negeri Padang \\ a)ranovrandinovrizal@gmail.com, b)jumiati.upik1962@gmail.com
}

\begin{abstract}
The Government of the Republic of Indonesia has basic functions, namely as empowerment, development and services. One of the functions of government as a service is to provide services for identity and citizenship rights. This study aims to determine how services and supporting factors as well as constraints in the service of making birth certificates at the Department of Population and Civil Registration of Kuantan Singingi Regency. The results showed that the service for making birth certificates at the Department of Population and Civil Registration of Kuantan Singingi Regency was seen from the following 6 public service standards: (1) service procedures, simple service procedures and easy to understand by the community; (2) completion time, the completion time is still uncertain; (3) service fees, free costs; (4) service products, service products in accordance with the wishes of the community; (5) incomplete facilities and infrastructure, facilities and infrastructure; (6) Competence of service providers, officers have served in a friendly and fair manner. Service support factors are awareness and regulatory factors. The inhibiting factors are the lack of infrastructure, human resources and lack of public awareness.
\end{abstract}

Keywords : Public Service, Birth Certificate

Corresponding author. Email. ranovrandinovrizal@gmail.com

How to cite this article. Novrizal, Randi \& Jumiati. (2020). Pelayanan Pembuatan Akta Kelahiran di Dinas Kependudukan dan Pencatatan Sipil Kabupaten Kuantan Singingi. Jurnal Mahasiwa Ilmu Administrasi Publik (JMIAP) Jurusan Ilmu Administrasi Negara Fakultas Ilmu Sosial Universitas Negeri Padang, Volume 2 (4), Hal. 36-43.

http://jmiap.ppj.unp.ac.id

ISSN : 2684-818X (Online), ISSN : 2338-7378 (Print)

Copyright $\bigcirc 2020$. Published by Labor Jurusan Ilmu Administrasi Negara FIS UNP, Padang 


\section{PENDAHULUAN}

Pemerintah Republik Indonesia mempunyai fungsi dasar yaitu sebagai pemberdayaan, pembangunan serta pelayanan. Dalam fungsi pemerintah sebagai pelayanan salah satunya yaitu memberikan pelayanan hak identitas dan kewarganegaraan. Menurut Dwiyanto (2012:20) setiap pelayanan dokumen kependudukan yang diselenggarakan sebagai bentuk jaminan dari negara untuk hak dan kebutuhan dasar warga negara disebut pelayanan administratif. Peristiwa kelahiran adalah salah satu peristiwa penting yang harus dicatat dan diterbitkan akta kelahirannya untuk setiap anak sebagai mana diatur dalam UU No 24 Tahun 2013.

Kuantan Singingi adalah kabupaten yang bertempat di Provinsi Riau dengan penduduk tersebar di 15 kecamatan. Pertumbuhan penduduk dan perkembangan masyarakat yang semakin meningkat berdampak pada kebutukan dokumen kendudukan semakin tinggi. Pada tahun 2016 diterbitakanlah Peraturan Bupati Kuantan Singingi Nomor 32 yang menegaskankan bahwa urusan pemerintahan dalam bidang kependudukan dan pencatatan sipil unsur pelaksananya adalah Dinas Kependudukan dan Pencatatan Sipil Kabupaten Kuantan Singingi.

Dalam menjalankan tugas dan fungsinya Dinas Kependudukan dan Pencatatan Sipil memiliki visi yaitu "Terwujudnya Penyelenggaraan Administrasi Kependudukan Yang Efektif, Tepat Dan Benar". Namun dalam kenyataannya di wilayah Kabupaten Kuantan Singingi dilansir dari surat kabar online Riaul.Com masih banyak terdapat anak yang belum memiliki akta kelahiran, sebagian sudah memiliki akta kelahiran tetapi akta kelahiran yang lama warna kuning.

Dari segi pelayanan permasalahan yang terjadi dalam penerbitan akta kelahiran yaitu sering bermasalah dengan jaringan, kurangnya persyaratan dari pemohon atau masyarakat dan tidak adanya kepastian hari penyelesain pembuatan akta kelahiran tersebut. (Hasil wawancara, tanggal 10 januari 2020).

Selain permasalahan diatas, yang menjadi permasalahnnya berdasarkan observasi peneliti adalah belum terpenuhinya standar pelayanan dari segi sarana-prasarana, seperti ruang tunggu tergolong sempit, karna dalam proses pelayanan tidak hanya masyarakat yang mengurus akta kelahiran saja tetapi dibidang lain juga seperti mengurus kartu keluarga dan sebagainya.

Jarak kantor juga tergolong jauh bagi masyarakat yang berada di Kecamatan Hulu Kuantan, Pucuk Rantau, dan Cirenti. Sehingga untuk pergi mengurus akta kelahiran ke Teluk Kuantan memerlukan biaya akomodasi perjalanan cukup besar. maka dari itu peneliti akan membahas tentang pelayanan pembuatan akta kelahiran di Dinas Kependudukan dan Pencatatan Sipil Kabupaten Kuantan Singingi.

\section{TINJAUAN PUSTAKA Konsep Pelayanan Akta Kelahiran}

Kurniawan dalam Mulyadi(2016:39) mengartikan bahwa pelayanan publik itu melayani keperluan orang atau pemberian pelayanan kepada masyarakat yang mempunyai kepentingan terhadap organisasi itu sesuai dengan tata cara dan aturan pokok yang telah ditentukan.

Adapun standar pelayanan publik yang menjadi jaminan bagi masyarakat atau pengguna layanan untuk memperoleh kepastian pelayanan sebagaimana ditegaskan dalam Keputusan Menteri PAN Tahun 2003 No 63, yaitu:

1) Prosedur pelayanan

2) Waktu penyelesaian pelayanan

3) Biaya dalam pelayanan

4) Produk jasa

5) Sarana dan prasarana dalam pelayanan

6) Kompetensi penyedia layanan atau pegawai pelayanan. 
Pelayanan akta kelahiran adalah pelayanan indentitas diri setiap anak yang dituangkan dalam bentuk akta kelahiran sebagai bentuk pengakuan dari negara yang ditegaskan secara jelas dalam Undang Undang Perlindungan Anak Tahun 2014 Nomor 35. Pelaksanaan pelayanan akta kelahiran diatur dalam Perpres No 96 Tahun 2018 pasal 63 yang dilaksanakan melalui tahapan:

1) Pelaporan. Pemohon atau pelapor mendatangi petugas pelayanan untuk penerbitan akta kelahiran;

2) Verifikasi dan validasi. Pegawai memeriksa kelengkapan berkas data pemohon/pelapor;

3) Perekaman data. Pegawai atau tenaga operator mengentry data kedalam data base dan mencetak akta kelahiran;

4) Pencatatan dan penerbitan dokumen. Penulisan buku register akta kelahiran oleh kepala seksi dan kepala bidang, penandatanganan dokumen akta kelahiran oleh kepala dinas, petugas melakukan pengarsipan dan terakhir pengambilan dokumen akta kelahiran oleh pemohon di loket pelayanan dan diperiksa pemohon.

Untuk mendapatkan akta kelahiran ini ada beberapa persyaratan pelayanan yang harus di penuhi sesuai aturan pokok yang telah ditetapkan yaitu keterangan kelahiran anak, Akta perkawinan/buku nikah orang tua atau bukti lain yang sah, KTP-e1 serta KK, berita acara dari Kepolisian, SPTJM tentang kelahiran dengan Saksi 2 (dua) orang.

Proses penerbitan dokumen akta kelahiran selambat-lambatnya 14 hari kerja setelah berkas diterimah dengan lengkap. Biaya pengurusan atau pembuatan akta kelahiran secara keseluruhan gratis sesuai dengan Pasal 79 A UU No 24 tahun 2013 yang isinya menyatakan bahwa segala bentuk pelayanan dokumen kependudukan bebas biaya atau gratis. Pelayanan publik akan berjalan sesuai harapan jika didukung oleh beberapa faktor yaitu faktor kesadaran dari pegawai pelayanan, faktor aturan, faktor organisasi, faktor pendapatan pegawai, faktor kemampuan dan keterampilan pegawai, dan faktor sarana atau fasilitas pelayanan. (Moenir, 2015).

Setiap pelayanan tentu tidak selalu dapat berjalan secara maksimal sesuai harapan. Tentu aja saja yang mempengaruhi dan menjadi penghambat pelaksanaannya. Menurut Selpianti(2016) faktor penghambat dalam penerbitan akta kelahiran yaitu kurangnya kesadaran dari masyarakat atas begitu berharganya dokumen pencatatan sipil, kurangnya sarana operasional seperti kendaraan untuk melakukan pelayanan serta terbatasnya anggaran untuk pembuatan website pelayanan kependudukan secara online sehingga masyarakat terhambat dan tidak bisa mengurus langsung secara online.

Selanjutnya Marhayana(2017) mengatakan bahwa faktor penghambat dalam pelaksanaan pelayanan akta kelahiran yaitu sebagai berikut:

a) Rendahnya kesadaran masayarakat terhadap pentingnya kepemilikan dokumen dan pemahaman masyarakat tentang kesadaran hukum masih minim.

b) Kurangnya fasilitas pelayanan dan sosialisasi dari pemerintah masih lamban

c) Orang tua tidak memiliki dokumen sebagai persyaratan seperti akta nikah

d) Masyarakat mengurus akta kelahiran anaknya hanya ketika ada kepentingan yang mendesak yang membutuhkan akta kelahiran

e) Masyarakat tidak tahu bahwa pelayanan gratis 
f) masyarakat merasa malas mengurus karena dan masyarakat kebanyakan sibuk kerja untuk mencari nafkah

\section{METODE PENELITIAN}

Penelitian ini adalah penelitian kualitatif yang menggambarkan serta menjelaskan kedalam berbentuk uraian dan analisis yang mendalam, suatu keadaan yang nyata tentang pelayanan pembuatan akta kelahiran di Dinas Kependudukan dan Pencatatan Sipil Kabupaten Kuantan Singingi. Dalam penelitian ini menentukan informan dengan metode purposive sampling. Informannya yaitu orang yang mengetahui permasalahan yaitu Kepala Dinas Kependudukan dan Pencatatan Sipil Kabupaten Kuantan Singingi, Kepala Seksi Kelahiran dan masyarakat pengguna layanan.

Sesuai dengan tujuan penelitian, maka data yang diambil adalah data primer dan data sekunder. Data primer yaitu data dari yang diperoleh hasil wawancara dengan informan. Data sekunder yaitu data yang berhubungan dengan keadaan geografis daerah lokasi penelitian termasuk dokumen dan arsip, profil yang diterimah dari Kantor Dinas Kependudukan dan Pencatatan Sipil Kuantan Singingi. Adapun teknik menguji keabsahan data yang digunakan adalah sebagai berikut (Moleong 2012:330), yaitu Teknik ketekunan pengamatan dan Teknik triangulasi. Pelaksanaan analisis data dilakukan memakai kegiatan reduksi data, pejajian data (display data), membuat kesimpulan serta verifikasi.

\section{HASIL DAN PEMBAHASAN}

Pelayanan Pembuatan Akta Kelahiran Di Dinas Kependudukan Dan Pencatatan Sipil Kabupaten Kuantan Singingi

Hasil penelitian menunjukkan bahwa pelayanan pembuatan akta kelahiran di Dinas Kependudukan Dan Pencatatan Sipil Kabupaten Kuantan Singingi bisa dinilai dari beberapa indikator sebagai berikut:

1. Prosedur Pelayanan
Prosedur pelayanan yaitu jenjang yang wajib dilalui dan dilaksanakan dalam pelayanan. Faktanya Prosedur pelayanan khususnya akta kelahiran mudah dipahami dan dilaksanakan oleh masyarakat. Masyarakat datang dengan membawa persyaratan seperti surat keterangan kelahiran anak, kartu keluarga dan buku nikah menemui pegawai yang berada difront office atau loket pelayanan. Pegawai menerimah bahan, diverifikasi dan validasi, bila bahan lengkap langsung diproses, diinput datanya oleh operator dan diajukan ke kasi bidang kelahiran. Kemudian kepala dinas melakukan TTE(tanda tangan elektronik) dimanapun beliau berada tidak harus bertatap muka. Kenyataan sesuai dengan Perpres No 96 Tahun 2018 yang secara garis besar menegaskan proses pelayanan yaitu pelaporan, verifikasi dan validasi, perekaman dan penerbitan. serta sesuai dengan prinsip pelayanan bahwa prosedur dalam pelayanan publik itu harus sederhana mudah dipahami agar tidak mempersulit masyarakat dalam pengurusan.

\section{Waktu Penyelesaian}

Dalam pelayanan penjamin kepuasan pengguna layanan adalah waktu. Waktu penyelesaian pelayanan perlu ditentukan mulai sejak awal masyarakat pelapor mengajukan permintaan sampai dengan proses akhir pelayanan. Semakin singkat waktu yang digunakan untuk menyelesaikan, maka kepercayaan dari masyarakat pengguna layanan akan semakin meningkat terhadap pelayanan yang diberikan pemerintah tersebut.

Proses penerbitan dokumen akta kelahiran dalam peraturan selambatlambatnya 14 hari kerja setelah berkas diterimah dengan lengkap. Kenyataanya, waktu penyelesaiannya tidak pernah melebihi 14 hari tapi untuk kepastian waktu penyelesain tidak ditentukan sejak awal masyarakat mengajukan permohonan. masyarakat hanya menunggu sms atau kabar dari kantor ke nomor hp masyarakat yang didaftarkan saat pengajuan. Dalam hal 
ini tentu tidak sesuai dengan prinsip pelayanan yang menyatakan bahwa harus adanya kepastian waktu. Karena bila hanya menunggu kabar berarti tidak adanya kepastian yang diberikan oleh pihak pelayanan.

\section{Biaya Pelayanan}

Ketidakpercayaan

masyarakat pengguna layanan kepada pegawai atau pemberi pelayanan dapat disebabkan oleh biaya pelayanan. Oleh sebab itu rincian biaya pelayanan harus ditetapkan secara konsisten tidak berubah-ubah serta juga tidak boleh adanya diskriminasi atau perbedaan perlakuan pelayanan. Pelayanan akta kelahiran gratis atau tanpa dipungut biaya sehingga tidak membebani masyarakat. Biaya pengurusan atau pembuatan akta kelahiran secara keseluruhan gratis sesuai dengan undangundang yang diterbitkan tahun 2013 nomor 24 pada pasal 79 A yang isinya menjelaskan bahwa pengurusan dokumen kependudukan bebas dari biaya.

\section{Produk Pelayanan}

Hasil atau keluaran dari pengajuan permohonan pelayanan adalah produk pelayanan. Dalam pelayanan akta kelahiran yaitu diterbitkannya akta kelahiran. Produk atau hasil dari pelayanan yang diberikan kepada masyarakat sudah memuaskan. Produk pelayanan sudah sesuai dengan harapan masyarakat pengguna pelayanan. Hal ini sudah menjalankan prinsip penyelenggaran pelayanan yaitu akurasi, ketepatan dan kebenaran produk pelayanan.

\section{Sarana dan Prasarana}

Kesiapan sarana-prasarana atau fasilitas yang lengkap akan berdampak kepada rasa nyaman kepada masyarakat pengguna layanan yang datang mengurus keperluan. Kenyataannya masih minim, membuat masyarakat yang mengurus akta kelahiran merasa kurang betah. Ruang tunggu pelayanan masih tergolong sempit, tidak memenuhi syarat pelayanan yang melayani banyak keperluan masyarakat. Masyarakat yang datang tidak hanya dalam pengurusan akta kelahiran tetapi ada yang mengurus akta kematian, surat pindah dan lain sebagainya. Hal ini menyimpulkan bahwa dalam prinsip pelayanan yaitu memberikan kenyaman pelayanan belum maksimal dan terpenuhi.

\section{Kompetensi Petugas Pemberi \\ Pelayanan \\ Perilaku, sikap, keterampilan,} pengetahuan, dan kemampuan adalah dasar utama dalam penetapan kompetensi petugas atau pegawai pemberi pelayanan. Keramahan, kesopan-santunan dan kedispilin pegawai adalah sebuah prinsip yang harus dilaksanakan dan dimiliki dalam pelayanan publik yang telah ditetapakan dalam peraturan.

Faktanya pegawai dalam memberikan pelayanan terhadap masyarakat tidak ada perbedaan perlakuan, pegawai atau pemberi pelayanan memperlakukan masyarakat sama. Tidak membedakan-bedakan baik agama maupun suku dari pengguna layanan. semua masyarakat yang berurusan pegawai layani dengan cara yang. Pegawai melayani pengguna layanan atau masyarakat pemohon dengan bersikap ramah dan sopan.

Faktor Penghambat Dan Pendukung Pelayanan Pembuatan Akta Kelahiran Di Dinas Kependudukan Dan Pencatatan Sipil Kabupaten Kuantan Singingi

\section{A. Faktor Pendukung Pelayanan}

Faktor pendukung pelayanan adalah faktor-faktor yang mempengaruhi pelayanan sehingga bisa membuat pelayanan tercapai sesuai tujuan, sebagai berikut:

1) Kesadaran

Dalam pelayanan publik kesadaran itu sangat diperlukan dari seorang pegawai atau pemberi pelayanan. Kesadaran dari diri pegawai akan menjadi dasar kesungguhan diri dalam bekerja, membuat semangat melakukan tugas dan tanggungjawab 
pekerjaan, sehingga berdampak pada hasil yang maksimal.

Dengan kesadaran yang ada pada pegawai atau petugas, dalam bekerja mereka akan melaksanakan tugasnya dengan bersungguh-sungguh, penuh semangat, disiplin dan penuh keikhlasan. Dalam bekerja kesadaran ini sungguh mempunyai peran yang vital dan sangat penting, dengan kesadaraan pada diri pegawaI akan mendorong pegawai memberikan pelayanan secara maksimal sesuai yang sesuai harapan dan keingingan dari masyarakat. Buktinya , faktor kesadaran pada diri pegawai sudah terlihat. Pegawai melaksanakan tugas sesuai tanggungjawab dan tugasnya. Bahkan pegawai melakukan kerja sampai malam, tidak berpatokan kepada bel pulang untuk menyelesaikan dokumen akta kelahiran masyarakat.

\section{2) Aturan}

Aturan adalah sesuatu yang sangat diperlukan karna sebagai alat pengatur setiap orang dalam bertidak dan berbuat. Tanpa adanya aturan, tindakan dan perbuatan orang akan berlangsung sesuai dengan keinginan setiap masing-masing pribadi orang. Kenayataanya memang memiliki aturan dalam pelaksanaan pelayanan.

Dengan keberadaan aturan, pelayanan akan berjalan sesuai apa yang diharapkan. Aturan-aturan seperti prosedur, mekanisme pelayanan akan membuat masyarakat mematuhi dengan sendirinya. Aturan sangat penting karena sebagai pengatur pegawai dalam menjalankan tugasnya sehingga tidak adanya penyimpangan.

\section{B. Faktor Penghambat Pelayanan}

Faktor penghambat pelayanan adalah faktor-faktor yang mempengaruhi pelayanan sehingga pelayanan tidak maksimal, sebagai berikut:
1) Kurang lengkapnya sarana dan prasarana

Dalam pelayanan faktor yang sangat vital dan urgen dalam menentukan kualitas pelayanan adalah sarana dan prasarana. Sarana dan prasaran disini maksudnya adalah semua fasilitas yang mempunyai fungsi sebagai alat untuk mewujudkan apa yang hendak dicapai dalam memenuhi permintaan orang atau masyarakat yang meminta pelayanan kepada organisasi kerja tersebut. Faktanya bahwa sarana dan prasarana kurang memadai. Peneliti melihat memang masih kurang nyaman, dapat dilihat dengan masih kurang luasnya ruang tunggu dan minimnya ketersediaan bangku atau tempat duduk untuk pemohon pelayanan mengantri, sehingga menyebabkan masyarakat yang antri duduk terlalu rapat dengan masyarakat pengguna pelayanan yang lain. Tentu fasilitas ini memberikan pengaruh terhadap pelayanan. Selanjutnya sering bermasalahnya dengan jaringan internet, disaat pengimputan lancar tapi disaat pelaksanaan tanda tangan elektronik tiba tiba hilang. Hal ini menjunjukan bahwa fasilitas penunjang pelayanan masih kurang.

\section{2) Kurang Sumber Daya Manusia}

Sumber daya manusia pada hakekatnya adalah orang yang bekerja dalam sebuah organisasi yang mempunyai tugas untuk mencapai tujuan dari organisasi tersebut. Termasuk salah satunya memberikan pelayanan terbaik kepada pengguna layanan atau masyarakat dibutuhkanlah aparatur pemerintah atau tenaga pegawai yang memadai secara kualitas dan kuantitas. Sesuai fakta masih terdapat kekosongan pegawai atau tenaga operator. Oleh sebab itu, dalam memberikan pelayanan pegawai atau petugas pelayanan merasa kesulitan, karena terkadang satu orang pegawai harus merangkap pekerjaan. Dengan keterbatasan tenaga pegawai dapat menghambat kerja pelayanan sehingga tidak berjalan secara maksimal. 
3) Kurangnya Kesadaran Masyarakat

Dinas kependudukan dan catatan sipil gagal dalam mewujudkan tertib administarsi kependudukan karena disebabkan partisipasi dari masyarakat dan kesadaran masyarakat dalam melaporkan peristiwa kependudukan seperti kelahiran masih minim. Masyarkat juga kurang memahami dan mengetahuai betapa pentingnya akta-akta catatan sipil dan dokumen kependudukan. Masyarakat malas mengurus dan hanya ingin membuat dokumen bila dibutuhkan saja seperti persyaratan anak masuk sekolah.

Sesuai dengan hasil observasi dan wawancara peneliti lakukan bahwa masyarakat Kuantan Singingi kurang memiliki kesadaran akan kepemilikan akta kelahiran sehingga malas untuk pergi mengurus akta kelahiran. Tidak hanya itu saja, dokumen sebagai persyaratan dalam pembuatan akta kelahiran seperti buku nikah, KTP orang tua ada yang tidak memilikinya, sehingga menghambat proses pembuatan akta kelahiran tersebut. Hal ini menunjukan memang masyarakat kurang memilki kesadaran dalam memiliki dokumen kependudukan.

Hasil penelitian ini sejalan dengan penelitian Selpianti (2016) dengan judul bahwa kurangnya kesadaran masyarakat menjadi penghambat pelayanan pembuatan akta kelahiran. Jadi memang kesadaran masyarakat mempengaruhi pelayanan bahkan menghambat pencapaian visi dalam mewujudkan Indonesia tertib administrasi kependudukan.

\section{PENUTUP}

Berdasarkan uraian diatas dapat diambil kesimpulan bahwa dilihat dari 6 standar pelayanan publik, pelayanan pembuatan akta kelahiran di Dinas Kependudukan dan Pencatatan Sipil Kuantan Singingi belum maksimal yaitu pada waktu penyelesaian dan sarana-prasarana pelayanan. Faktor pendukung pelayanan adalah faktor kesadaran dan faktor aturan. Selanjutnya faktor penghambat adalah sarana dan prasaran masih minim, kurangnya sumber daya manusia atau tenaga pegawai dan kurangnya kesadaran dari masyarakat. Beberapa saran dari penelitian ini, yaitu:

1. Membangun gedung yang refresentatif yang memiliki ruang tunggu yang lebih besar, toilet khusus laki-laki maupun perempuan, ruang menyusui, ruangan shalat serta tempat bermain anak.

2. Memperkuat dan menambah kualitas jaringan internet.

3. Mempunyai mobil pelayanan keliling.

4. Memberikan kepastian hari penyelesaian kepada pemohon atau masyarakat pengguna layanan.

5. Merekrut pegawai atau tenaga operator untuk melengkapi kekurangan sumber daya manusia.

\section{DAFTAR KEPUSTAKAAN}

Agus, Dwiyanto. 2011. Manajemen Pelayanan Publik:Peduli, Inklusif, Dan Kolaboratif. Yogyakarta: Gadjah Mada University Press.

Moenir, H.A.S. (2015). Manajemen Pelayanan Umum di Indonesia. Jakarta: PT. Bumi Aksara.

Moleong, Lexy J. 2012. Metodologi Penelitian Kualitatif. Bandung : PT Remaja Rosdakarya.

Mulyadi, Deddy Dkk. 2016. Administrasi publik untuk pelayanan publik. Bandung:Alfabeta.

$\begin{array}{lr}\text { Keputusan Menteri Pendayagunaan } \\ \text { Aparatur } & \text { Negara } \\ \text { Nomor:63/KEP/M.PAN/7/2003 } \\ \text { Tentang Pedoman Umum } \\ \text { Penyelenggaraan Pelayanan Publik. }\end{array}$

Undang Undang Nomor 24 Tahun 2013 Tentang Perubahan Atas UndangUndang Nomor 23 Tahun 2006 Tentang Administrasi Kependudukan. 
Randi Novrizal, Jumiatil Pelayanan Pembuatan Akta Kelahiran di Dinas Kependudukan dan Pencatatan Sipil Kabupaten Kuantan Singingi

Peraturan Bupati Nomor 32 tahun 2016 tentang Kedudukan, Susunan Organisasi, Tugas Dan Fungsi Serta Tata Kerja Dinas Kependudukan dan Pencatatan Sipil Kabupaten Kuantan Singingi.

Peraturan Presiden Nomor 96 Tahun 2018 Tentang Persyaratan Dan Tata Cara Pendaftaran Penduduk Dan Pencatatan Sipil.

Undang-Undang Nomor 35 tahun 2014 tentang Perubahan Atas UndangUndang Nomor 23 tahun 2002 tentang Perlindungan Anak.

Selpianti. 2016. Pelayanan Akta Kelahiran Oleh Dinas Kependudukan Dan Pencatatan Sipil Kota Batu. Jurnal Ilmu Sosial dan Politik. Vol. 5, No. 2 .

Marhayana. 2017. Pendaftaran Akta Kelahiran Anak Hasil Nikah Tanpa Akta nikah Pasca Putusan Mahkamah konstitusi nomor46/PuuViii/2010. Dalam Skripsi. Universitas Islam Negeri Alauddin Makassar.

Riau1.com. (2019, 28 September). 40.000 Anak di Kuansing Masih Belum Punya Akte Kelahiran. Diakses pada tanggal 12 November 2019. Dari https://www.riau1.com/berita/kuantansingingi/156967369540000-Anak-di Kuansing-Masih-Belum-Punya-Akte$\underline{\text { Kelahiran }}$ 